\title{
Investigation of the effects of different chelating solutions on the microhardness and surface roughness of root canal dentin
}

\author{
Celalettin Topbaş ${ }^{1}{ }^{(1}$, Özkan Adıgüzel ${ }^{2}{ }^{\circledR}$, Özlem Çölgeçen ${ }^{3}$ \\ ${ }^{1}$ University of Istanbul Health Sciences, Faculty of Dentistry, Department of Endodontics, İstanbul, Turkey. \\ ${ }^{2}$ Dicle University, Faculty of Dentistry, Department of Endodontics, Diyarbakır, Turkey. \\ 2 İzmir Katip Çelebi University, Faculty of Dentistry, Department of Prosthodontics, İzmir, Turkey.
}

\section{Correspondence:}

Dr. Celalettin TOPBAŞ

University of Istanbul Health Sciences, Faculty of Dentistry, Department of

Endodontics, İstanbul, Turkey.

E-mail:dt.c.topbas@gmail.com

Received: 16 November 2018

Accepted: 5 March 2019

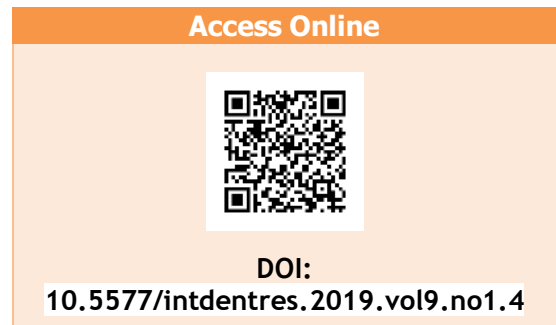

\begin{abstract}
Aim: The purpose of this study is to examine the effect of different chelating solutions on microhardness and surface roughness of root canal dentin.

Methodology: The crowns of sixty recently extracted maxillary central incisors were separated by diamond burs from the cemento-enamel junction. Roots are divided longitudinally into two pieces with diamond saw. The obtained samples were embedded in autopolymeric-acrylic and the dentin-surfaces of the teeth were grounded. Micro-hardness and surface-roughness measurements were carried out before the chelating processes. First group, the specimens were treated with gel-formed $17 \%$ Ethylenediaminetetraacetic acid [EDTA] (JE), second group, specimens were treated with $17 \%$ Liquid-formed EDTA (LE), third group, specimens were treated with $20 \%$ Citric acid (CA), and the last group specimens were treated with $7 \%$ Maleic acid (MA) for 120 seconds. After application of the chelating agents, micro-hardness and surface-roughness measurements of all samples were performed again. The difference between the initial and final measurements was calculated and statistically analyzed. One Way Analysis of Variance ANOVA was used for statistical-analysis and statistically significant difference was observed between the groups ( $p$ $<0.05$ ).
\end{abstract}

Results: According to the test results, the microhardness of LE was statistically equal to that of JE and caused the least decrease in microhardness, SA decreased micro-hardness more than LE and JE, and MA decreased dentin micro-hardness more than all other solutions. And surface-roughness results are: MA increased surface-roughness more than other groups, SA and JE less roughened the dentin surface than MA, and there was no significant difference between the two solutions, LE caused less increase in dentin surface roughness compared to all solutions.

Conclusions: Besides the use of EDTA and SA, the clinical use of MA can be considered, and it should also be noted that EDTA differs in terms of surface roughness between liquid and gel forms.

Keywords: Microhardness, surface roughness, gel EDTA, liquid EDTA, Citric acid, Maleic acid

How to cite this article: Topbaş C, Adıgüzel Ö, Çölgeçen Ö. Investigation of the effects of different chelating solutions on the microhardness and surface roughness of root canal dentin. Int Dent Res 2019;9(1):22-9. 


\section{Introduction}

When chemo-mechanical preparation is performed, the purpose is; removing the vital, infected or necrotic pulp from the root canal of the tooth, shaping the canals, removing microorganisms, and removing the dentin chips and smear layer during the preparation (1). When the endodontic preperation is performed with both hand and instrument systems, a smear layer is formed (2). The smear layer consists of an organic structure composed of organic and inorganic fractions of calcifying tissue, pulp tissue residues, odontoblastic cell structure, microorganisms and blood cells in dentin tubules (2). The thickness of this layer, which does not form on the surface of the unprepared root canals, is between 1-5 $\mu \mathrm{m}$; and it is changed by the shape, design and the sharpness of the instruments, and whether the dentin of the canal was wet or dry (2). In the past, the effect of the smear layer on the success rate of endodontic treatment was controversial. However, nowadays, the protection of this layer is recommended and techniques and products for this purpose are still being developed $(3,4)$.

Different irrigants were used to remove the smear layer. For example, CA, ethylenediamine tetraacetic acid (EDTA), tetracycline isomer (doxycycline), acid and detergent (Tween 80) mixture (MTAD) were used. However, the most commonly used solutions are EDTA and sodium hypochlorite (5-9). SA, an organic acid, is now the most commonly used chelating agent after EDTA (10). It has been used in many studies to remove the smear layer after mechanical preparation of the canals. One disadvantage of using CA is to leave residues in the form of crystal structures in the canals. As a result, some problems may occur in root canal filling $(5,10,11)$. MA is a soft organic acid used in adhesive dentistry. It is also used in restorative dentistry as roughening. In addition, in endodontics, it has been used to remove the smear layer at varying concentrations (5\%, $7 \%, 10 \%$, 15\%) (12).

These chemical agents cause changes in dentin structure and alter the ratio of calcium / phosphorus (Ca / P) in the dentin surface (13). These changes in the ratio of calcium and phosphorus cause a change in the ratio between organic and inorganic tissues (14). This affects the permeability and solubility of the dentin, and also the binding of dental materials such as resin-based cements and sealers to hard tissues (4). The chelating agents bind to the calcium ions in the hydroxyapatite crystals of the peritubular dentin and are responsible for decalcification. In this case, the hardness of the root canal dentin decreases and the roughness increases (15). Chelating agents soften the dentin by making chelats with calcium ions, thus providing an easier preparation. Acids generally demineralize dentin by breaking and weakening the bond between organic and inorganic structures (16, 17). The effects of various solutions on surface hardness and roughness of dentin have been investigated previously. (18-22). The aim of this study was to investigate the effects of four different chelating solutions (JE, LE, CA, MA) on microhardness and surface roughness of root canal dentin and to compare these solutions with each other.

\section{Materials and Methods}

In our study, 60 healthy maxillary incisor teeth were used which were extracted for periodontal reasons in patients between 25 and 50 years of age from both sexes. Care has been taken to ensure that the teeth are of similar morphology, that their roots are of similar length, that there are no cracks, fractures or caries, and that they have not received any restorative or endodontic treatment. Before the procedure, the periapical films of the teeth were taken and the teeth which were not proper for treatment were sieved by looking for any root canal calcification, internal or external resorption. And teeth with similar root canal width were selected. The specimens were stored at $37^{\circ} \mathrm{C}$ at $100 \%$ humidity for 2 weeks until the experiments performed. Access cavities opened with sterile dimond burs. After the pulp of the teeth were extirpated with the help of a tirnerf (Mani Inc-Tochigi Ken, Utsunomiya-shi, Japan), the crowns were separated from their roots by high speed diamond burs (Diatec, Coltene AG, Switzerland) from the enamelcement border under distilled water cooling. After removal of the crowns, the roots were vertically divided into two, starting from the cervical and proceeding to the apex with low-speed diamond disc (Isomet, Buehler Ltd., Lake Bluff, NY, USA) under distilled water cooling. The obtained samples were embedded horizontally (with the dentin parts exposed) to autopolymerisied acrylic (as each block contains 10 samples) (Figure 1). Then the exposed dentin surfaces of speciments which were embedded to acrylic were grounded smooth with a couple of increasing grades of abrasive carbide papers $(500,800,1000,1200$ grit) under cooling of distilled water to smooth all surface burs. And then, specimens were polished with $0.1 \mu \mathrm{m}$ alumina polishing paste (Ultra-Sol R, Eminess Tecnologies Inc., Monroe, NC, USA) on a circular felt disc machine (Figure 1).

The prepared blocks are divided into $M$ and $R$ groups. Microhardness in $M$ group, and surface roughness in $\mathrm{R}$ group. $M$ and $R$ groups are divided into 4 subgroups M1, M2, M3, M4 and R1, R2, R3, R4 in order to apply different chelating agents. The sample in each subgroup is also numbered (Table 1 ).

The samples in group $M$ were used to evaluate the dentin microhardness by Vickers microhardness test. The average microhardness values of the samples in each block before the chelating agents were applied were determined by using a Vickers microhardness meter (Shimadzu HMV-2, Japan). For each sample, 300 $\mathrm{g}$ force was applied for 20 seconds and 3 values were calculated at $0.5 \mathrm{~mm}$ distance from the root canal wall, one measurement from root cervical third, middle third and apical third. An average initial microhardness value was determined by averaging these three values. 
Table 1. Classification of teeth

\begin{tabular}{|ccccc}
\hline Groups & $\begin{array}{c}\text { Group M } \\
\text { (Microhardness) }\end{array}$ & $\begin{array}{c}\text { Number of } \\
\text { Teeth }\end{array}$ & $\begin{array}{c}\text { Group R } \\
\text { (Surface Roughness) }\end{array}$ & Number of Teeth \\
\hline $\mathbf{1 7 \%}$ Gel EDTA & $M 1$ & 15 & R1 & 15 \\
\hline $\mathbf{1 7 \%}$ Liquid EDTA & $M 2$ & 15 & R2 & 15 \\
\hline $\mathbf{2 0 \%}$ Citric Acid & M3 & 15 & R3 & 15 \\
\hline $7 \%$ Maleic Acid & M4 & 15 & R4 & 15 \\
\hline
\end{tabular}

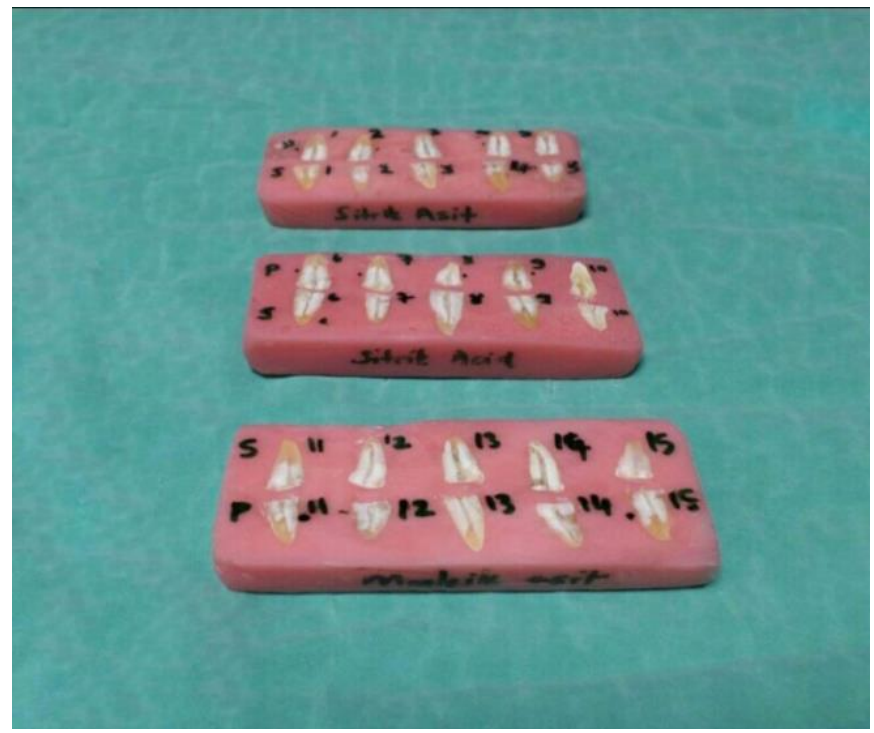

Figure 1. Prepared samples.

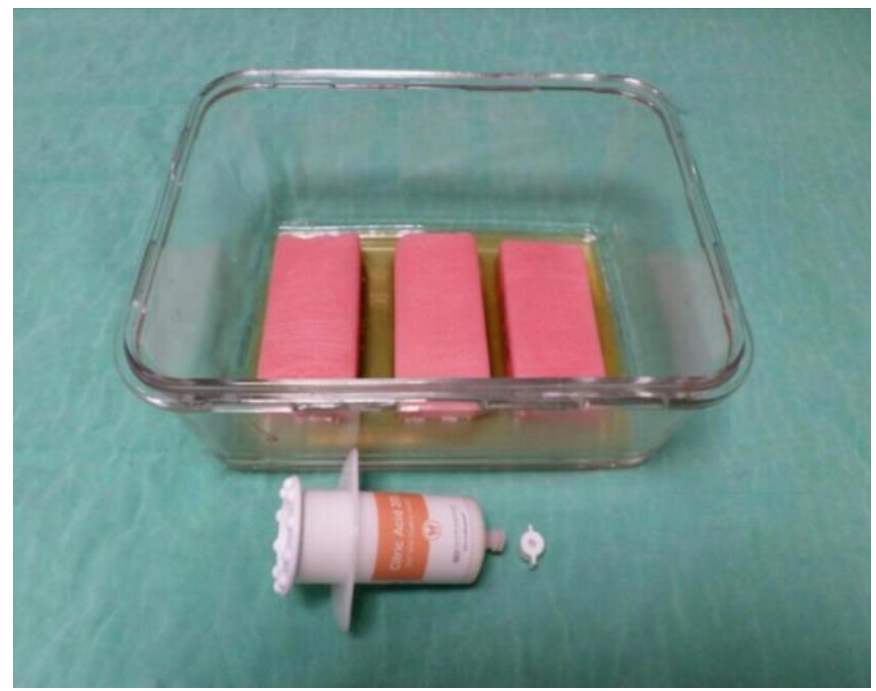

Figure 2. Chelation with $20 \% \mathrm{SA}$

For group M1, JE (i-EDTA, Medicinos Linja UAB, Lithuania), for group M2, LE (Prime Dental Products, PVT, Ltd., India), for group M3, CA (Ultradent Products, Inc., South Jordan), for group M4, MA (Dicle University Faculty of Medicine, Diyarbakir, Turkey) was applied for 120 seconds. The samples were immersed by facing down in a bowl, and the sample sides of the blocks immersed $3 \mathrm{~mm}$ in the solutions. The samples were then washed with distilled water and dried. After the irrigation process was finished, three microhardness measurements were made again on the same area of each sample with a Vickers microhardness tester and the averages were recorded as the final microhardness value.

The samples in group $\mathrm{R}$ were used to measure the surface roughness of the root canal dentin. The initial surface roughness measurement of all samples was performed using the Surftest roughness meter (Mitutoyo SJ 310, Japan). Five measurements were made from each sample. A total surface area of 1.25 $\mathrm{mm}$ in length was scanned such that each measurement had a length of $0.25 \mathrm{~mm}$ and a probe speed of $0.5 \mathrm{~mm}$ / s. The arithmetic average of the 5 values was taken. This average value obtained is recorded, as the initial surface roughness value of the sample. JE for group R1, LE for group R2, SA for group R3 (Figure 2) and MA for group R4 for 120 seconds. Then the samples were washed with distilled water and dried. After this 2 minutes of chelation procedure was finished, the Surftest roughness device was used for scan again from each sample surface. The averages of the obtained values were recorded as the final surface roughness value. ANOVA One Way Analysis of Variance was used to test whether there was a statistically significant difference between before and after irrigation with chelating solutions.

\section{Statistical Analysis}

Statistical analysis of the results obtained with the Statistical Package for Social Sciences (SPSS) statistics 21.0 for Windows package program (SPSS Inc., Chicago, (L, USA). The detected microhardness and surface roughness values were used. A statistical analysis was performed on the difference values between the mean initial and final values of the groups. ANOVA One Way Analysis of Variance was used to compare the difference values of the groups in the statistical study $(p<0.05)$. The results are given with $95 \%$ confidence intervals. 


\section{Results}

According to the statistical test results, there was a significant difference between some of the groups ( $p$ $<0.05$ ) and no significant difference between the other groups ( $p>0.05)$. There was a decrease in microhardness in all groups (Table 2) while an increase in surface roughness was observed (Table 3). The difference between the microhardness values before and after application of the chelating solutions was calculated. According to statistical analysis of these calculated difference values, Tukey comparison test was performed. According to this;

- There was no statistically significant difference between JE and LE in terms of microhardness reduction (p>0.05).

- There was a statistically significant difference between $\mathrm{JE}$ and CA in terms of microhardness reduction $(p<0,05)$.
- There was a statistically significant difference between JE and $M A$ in terms of microhardness reduction $(p<0.05)$.

- There was a statistically significant difference between LE and CA and between LE and MA in terms of microhardness reduction $(p<0,05)$.

- There was a statistically significant difference between SA and $M A$ in terms of microhardness reduction $(p<0,05)$.

According to these findings, there was no statistically significant difference between microhardness values after LE and JE application on dentin. Both solutions were found to cause the least decrease in microhardness. It was found that CA caused more reduction in microhardness than EDTA solutions and MA decreased microhardness more than all other solutions (Graph. 1).

Table 2: Effect of root dentin on chelating agents on microhardness

\begin{tabular}{lcccc}
\multicolumn{1}{c}{ Groups } & N & $\begin{array}{c}\text { First Microhardness } \\
\text { Value }(\mathrm{HV})\end{array}$ & $\begin{array}{c}\text { Final } \\
\text { Microhardness } \\
\text { Value (HV) }\end{array}$ & $\begin{array}{c}\text { Difference of } \\
\text { Microhardness } \\
\text { Values (HV) }\end{array}$ \\
\hline 17\% Gel EDTA & 15 & 58,58 & 45,56 & 13,02 \\
$17 \%$ Liquid EDTA & 15 & 61,45 & 50,16 & 11,29 \\
$20 \%$ Citric Acid & 15 & 57,21 & 41,78 & 15,43 \\
$7 \%$ Maleic Acid & 15 & 59,06 & 38,87 & 20,19 \\
\hline
\end{tabular}

Graphic 1: Analysis graphic of microhardness difference data of solutions

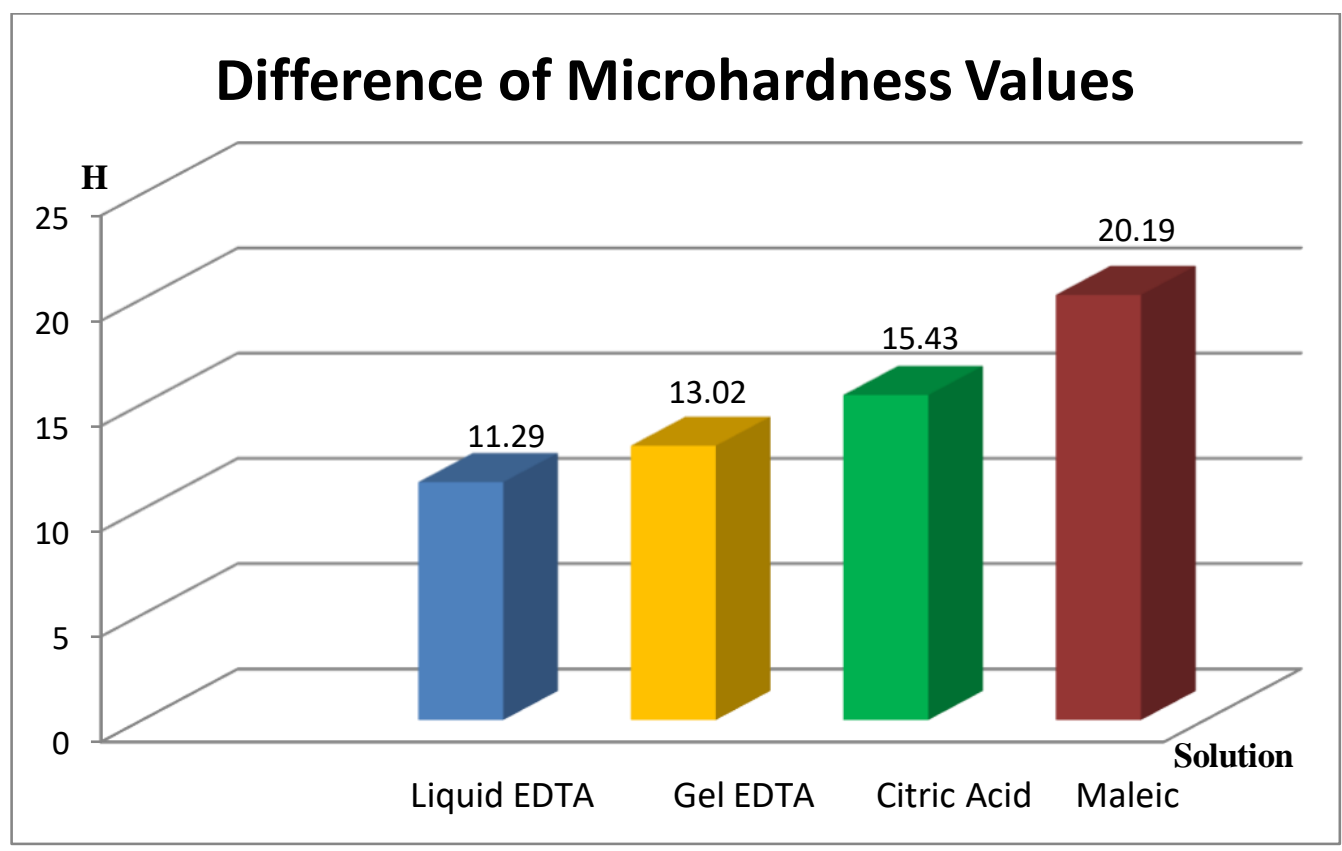


The difference between the surface roughness values before and after application of the chelating solutions was calculated. Tukey binary comparison test was performed according to the statistical analysis of these calculated difference values. According to this;

- There was a statistically significant difference between JE and LE and between JE and MA in terms of roughening of the dentin surface $(p<0,05)$.

- There was no statistically significant difference between JE and SA in terms of increasing surface roughness ( $p>0.05)$.
- There was a statistically significant difference between LE and SA and between LE and MA in terms of roughening of the dentin surface $(p<0,05)$.

- There was a statistically significant difference between SA and MA in terms of increasing surface roughness $(p<0.05)$. The solution that minimally increased the roughness value on the dentin surface was the LE solution.

There was no statistically significant difference between JE and SA, and both solutions caused more dentin surface roughness than LE. The solution that maximally increased the roughness value was MA (Graph. 2).

Table 3: Effect of chelating agents on root dentin surface roughness

\begin{tabular}{lcccc}
\multicolumn{1}{c}{ Groups } & $N$ & $\begin{array}{c}\text { First Roughness } \\
\text { Value }(\mu \mathrm{m})\end{array}$ & $\begin{array}{c}\text { Final Roughness } \\
\text { Value }(\mu \mathrm{m})\end{array}$ & $\begin{array}{c}\text { Difference of } \\
\text { Roughness } \\
\text { Values }(\mu \mathrm{m})\end{array}$ \\
\hline 17\% Gel EDTA & 15 & 0,171 & 0,358 & 0,187 \\
$17 \%$ Liquid EDTA & 15 & 0,186 & 0,315 & 0,129 \\
20\% Citric Acid & 15 & 0,194 & 0,399 & 0,205 \\
$7 \%$ Maleic Acid & 15 & 0,221 & 0,526 & 0,305
\end{tabular}

Graphic 2: Analysis graphic of surface roughness difference data of solutions

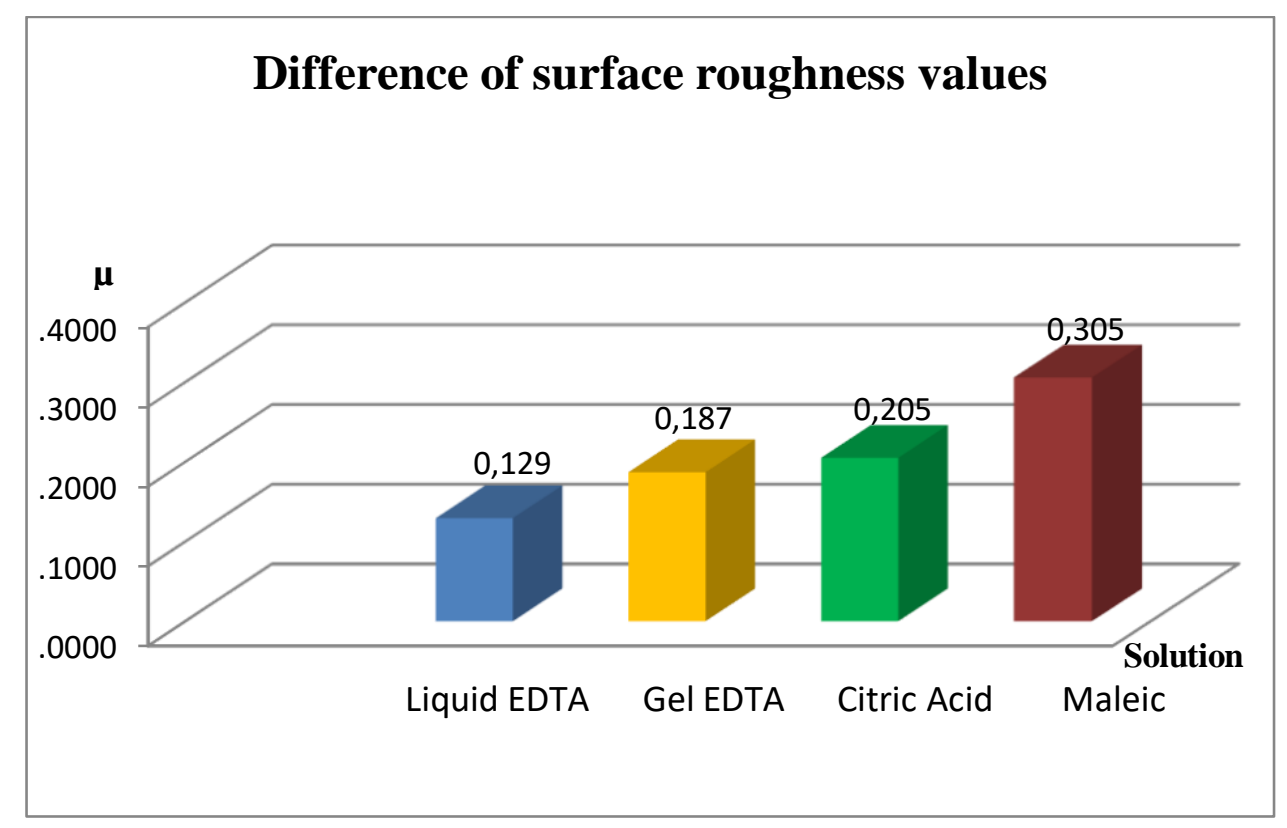

\section{Discussion}

During the biomechanical shaping of the root canals, a smear layer, an amorphous layer, is formed by the addition of bacterial structures to the organic and inorganic debris and covers the dentinal surfaces that the file contacts $(2,13,23)$. It is advised to remove this layer before the root canal obturation to ensure a firm connection between the sealers and the dentin surface. In order to remove the smear layer, it is necessary to use solutions having both organic and inorganic tissue dissolution qualities (24). It has been claimed that the chelating agents dissolve the inorganic part of the smear layer (25) and that the organic part is also removed if used in combination with $\mathrm{NaOCl}$. It has been argued that this combined method will be the most effective method for completely removing the smear layer from the dentin surface (2). The inorganic tissue dissolving effect of chelating agents is that these 
solutions dissolve the calcium content of the hydroxyapatite crystals of dentin. Any change in the ratio of dentin calcium leads to a distinct difference between the organic and inorganic structures of the dentin, thus changing the permeability, solubility, microhardness, and surface roughness of the dentin (26). According to the results obtained from our study, if a ranking is made in terms of the ability to reduce microhardness, the following conclusion can be reached:

\section{$\mathrm{LE}=\mathrm{GE}<\mathrm{CA}<\mathrm{MA}$}

Some studies support these results $(27,28,29)$. In some previous studies, knoop microhardness test and vickers microhardness test methods were used to measure dentin microhardness $(30,31)$. Oliveira and Carvalho argued that the Vickers microhardness test was easier and more specific for dentin to assess differences due to mineral loss on the dentin surface of chelating solutions $(30,32)$. For this reason, this test method has been utilized in our work. In addition, in order to examine the effects of chelating agents on the root in vitro in our study, the roots were vertically divided into two halves and measurements were made at 3 different points.

The microhardness of the dentin varies with different regions of the root and the hardness values decrease as the pulp approaches (33). Pashley and colleagues reported that the microhardness of the dentin decreased as it progressed from the outer surface to the center (30). The reason for this is argued that large number of wide dentin tubules near the pulp and the tubules without peritubular dentin are less resistant to the pressure-applying tip of the test device $(34,35)$. In our study, the reason of even the same tooth has different values is, microhardness measurements can be related to measurements made at different points of the tooth. There are a number of studies that apply chelating solutions at different times, but no consensus has yet been reached on the duration of application $(29,36,37)$. The contact times of the chelating solutions vary from 1 minute to 10 minutes in the studies $(38,39)$. In a study conducted by Çalt and Serper, 2-minute irrigation with 17\% EDTA indicated that the smear layer completely disappeared and the optimum duration was 2 minutes (39). In our study MA, CA, JE and LE were applied for 120 seconds. In a study smear layer removal activities of $M A$ and EDTA, 17\% EDTA and 7\% MA were used. In the apical third, which is one of the most critical regions for success in root canal treatment, MA clearly removes the smear layer more effectively than EDTA (40), while there is no significant difference in the removal of the smear layer in the coronal and midthird of the teeth. We have included MA which is not commonly used to our study, in order to compare it with solutions such as EDTA and SA, which are more commonly used than MA. In many studies, EDTA has been shown to reduce the microhardness of root dentin $(15,41)$. Recently, the successive use of $7 \%$ MA and $2.5 \%$ sodium hypochlorite has been achieved to be much better than EDTA in removing smear layer from root dentin (40). One of the most commonly used chelation agents in endodontics is SA (42). In a study comparing the use of $17 \%$ EDTA followed by $5.25 \% \mathrm{NaOCl}$, and $19 \% \mathrm{SA}$ and then $5.25 \%$ $\mathrm{NaOCl}$ in terms of dentin microhardness and surface roughness; SA group reduced dentin microhardness more. And in terms of surface roughness, the SA group roughened the dentin surface more than the EDTA group (28). MA is more biocompatible than EDTA, so it is advised to substitute EDTA clinically $(43,44)$. It is recommended to use $M A$ at a maximum concentration of $7 \%$, because concentration of $10 \%$ or more causes demineralization and damage to root canal walls (12). The softening effect of chelating agents on dentin can be of clinical benefit because it can help to ease and accelerate the preparation procedure and help to negotiate narrow channels more easily. The degree of softening and demineralization may have an impact on fracture resistance, with the physical and chemical properties of the dentine structure (28).

Chelating agents have liquid and gel forms on the market. However, since there are not many studies comparing gel and liquid forms, two different forms of EDTA have been included. All of the chelating agents we used in the study have been shown to enhance dentin surface roughness. Previous work supports the results of our work $(28,29)$. The release of chelating agents from inorganic tissues of the dentin and the appearance of the dentin tubules and collagen structure can be thought of as the cause of surface roughness. Studies investigating the effects of irrigation solutions on surface roughness have been reported to cause an increase in surface roughness of $\mathrm{NaOCl}$. This effect is reported to be due to the ability of $\mathrm{NaOCl}$ to dissolve organic tissues $(40,45)$. In a study investigating the effects of different chelating solutions on surface roughness, MA caused much more surface roughness than EDTA (29). This may be due to the MA's stronger demineralizing effect than EDTA and its success in removing the smear layer. In the same study, in dentin samples applied MA, the dentin surface was completely free from the smear layer and the dentin tubules became clear. As the dentin microhardness decreased, the surface roughness increased (29). These results overlap with the results of our study. The increase in surface roughness can be of clinical benefit as restorative dentistry also increases the bond strength of resin-containing fillers $(29,46)$. Roughened surfaces can also provide a clinical benefit for adhesive sealers that require surface roughness and irregularities for micromechanical bonding $(15,40,47)$. If these roughnesses on the surface increase too much, it is suggested that voids may form in the adhesion of the sealers in this case, resulting in bacterial colonization and leakage after the hermetic obturation can not be fully achieved. It has been reported that attention should be paid in the use of chelating solutions due to these risks and demineralising effects $(48,49,50,51)$. If a ranking is made in terms of their ability to increase surface roughness according to the results obtained from our study,

\section{$\mathrm{LE}<\mathrm{JE}=\mathrm{CA}<\mathrm{MA}$}

When the surface roughness and microhardness test results are examined, it is seen that MA has the highest roughness and demineralizing effect on the root 
canal dentin surface. In areas where the dentin tissue is thin like furcation, the possibility of perforation increases in the case of careless operation and excessive reduction in microhardness may cause cracks in dentin. Therefore, the use of chelates should be very careful. In our study, $7 \%$ MA produced a higher level of dentin surface roughness than both types of EDTA and $20 \%$ SA and decreased the microhardness more than $17 \%$ LE. Although this is considered to be a clinical advantage, attention should be paid to the contact times of the solutions against fractures that may occur in the roots. Accordingly, studies on the fracture resistance of dentin can be performed. Furthermore, due to the increase in dentin surface roughness, new studies on penetration depth and impermeability of endodontic sealers are needed.

\section{Conclusions}

According to the results obtained without this study, besides the use of EDTA and SA, the clinical use of MA can be considered. However, because the MA reduces denture microhardness more than other agents and causes more roughness on the dentin surface, its suitability for clinical use is controversial. It should also be noted that EDTA differs in terms of surface roughness between liquid and gel forms. For this reason, in-vitro and clinical studies to be performed in the future require accurate calculation of the profitloss ratio and more accurate results are to be achieved.

Ethical Approval: Ethics committee approval was received for this study from Dicle University.

Peer-review: Externally peer-reviewed.

Author Contributions: Conception - C.T., Ö.A.; Design - C.T., Ö.A.; Supervision-Ö.A.; Materials-C.T., Ö.Ç.; Data Collection and/or ProcessingC.T., Ö.A.; Analysis and/or Interpretation - C.T., Ö.C..; Literature Review C.T., Writer-C.T., Critical Review-Ö.A.

Conflict of Interest: No conflict of interest was declared by the authors.

Financial Disclosure: This work was supported by Research Fund of the Dicle University. Project Number: Diș.15.013

\section{References}

1. Baumgartner JC, Cuenin PR. Efficacy of several consantrations of sodium hypochlorite for root canal irrigation. J Endodon 1992;18:605-12. (Crossref)

2. Sen $B H$, Wesselink $P R$, Türkün $M$. The smear layer: $A$ phenomenon in root canal therapy. Int Endod J 1995;28:141-8. (Crossref)

3. Goldberg DB, Abromovich A. Analysis of the effect of EDTAC on the dentinal walls of the root canal. J Endod 1977;3:101-5. (Crossref)

4. Shahravan A. Haghdoost A, Adl A, Rahimi H, Shadifar F. Effect of smear layer on sealing ability of canal obturation: a systematic review and meta-analysis. J Endod 2007;33:96-105. (Crossref)

5. Wayman BE, Kop WM, Pinero GJ, Lazzari EP. Citric and lactic acids as root canal irrigants in vitro. J Endod 1979;5:258-65. (Crossref)

6. Aktener BO, Bilkay U. Smear layer removal with different concentrations of EDTA-Ethylenediamine mixture. J Endod 1993;19:228-31. (Crossref)

7. Torabinejad M, Khademi AA, Babagoli J, Cho Y, Johnson WB, Bozhilov K, Kim J, Shabahang S. A new solution for the removal of the smear layer. J Endod 2003;29:170-5. (Crossref)

8. Calt S, Serper A. Smear layer removal by EGTA. J Endod 2000;26:459-61. (Crossref)

9. Zehnder M. Root canal irrigants. J Endod 2006;32:389-98. (Crossref)

10. Baumgartner JC, Brown CM, Mader CL, Peters DD, Schulman JD. A scanning electron microscopic evaluation of root canal debridement using saline, sodium hypochlorite and citric acid. J Endod 1984;10:525-31. (Crossref)

11. Tidmarsh BG. Asid-cleansed and resin-sealed root canals. J Endod 1978;4:117-21. (Crossref)

12. Prabhu SG, Rahim N, Bhat KS, Mathew J. Comparison of removal of endodontic smear layer using $\mathrm{NaOCl}$, EDTA, and different concentrations of maleic acid: A SEM study. Endodontology 2003;15:20-5.

13. Hennequin $M$, Pajot J, Avignant D. Effects of different $\mathrm{pH}$ values of citric acid solutions on the calcium and phosphorus contents of human root dentin. J Endod 1994;20:551-4. (Crossref)

14. Rotstein I, Dankner E, Goldman A, Heling I, Stabholz A, Zalkind M. Histochemical analysis of dental hard tissues following bleaching. J Endod 1996;22:23-6. (Crossref)

15. Ari H, Erdemir A, Belli S. Evaluation of the effect of endodontic irrigation solutions on the microhardness and the roughness of root canal dentin. J Endod 2004;30:792-5. (Crossref)

16. Baumgartner JC, Brown CM, Mader CL, Peters DD, Schulman JD. A scanning electron microscopic evaluation of root canal debridement using saline, sodium hypochlorite and citric acid. J Endod 1984;10:525-31. (Crossref)

17. Harrison JW. Irrigation of the root canal system. Dent Clin Nort Am 1984;28:797-808.

18. Chang HK, Palamara JE, Messer HH. Effect of hydrogen peroxide and sodium perborate on biomechanical properties of human dentine. J Endod 2002;28:62-7. (Crossref)

19. Saleh A, Ettman W. Effect of endodontic irrigation solutions on microhardness of root canal dentine. J Dent 1999;27:43-6. (Crossref)

20. Cruz-Filho AM, Sousa-Neto MD, Saquy PC, Pécora JD. Evaluation of the effect of EDTAC, CTDA and EGTA on radicular dentine microhardness. J Endod 2001;27:183-4. (Crossref)

21. Zhang K, Kim YK, Cadenaro M, Bryan TE, Sidow SJ, Loushine RJ, Ling JQ, Pashley DH, Tay FR. Effects of different exposure times and concentrations of sodium hypochlorite/ethylenediaminetetraacetic acid on the structural integrity of mineralized dentin. J Endod 2010;36:105-9. (Crossref)

22. Moreira DM, Almeida JFA, Ferraz CCR, Gomes BPFA, Line SRP, Zaia AA. Structural analysis of bovine root dentin after use of different endodontics auxiliary chemical substances. J Endod 2009;35:1023-7. (Crossref)

23. Sim TP, Knowles JC, Shelton J, Gulabilava K. Effect of sodium hypochlorite on mechanical properties of dentine and tooth surface strain. Int Endod J 2001;34:120-32. (Crossref)

24. Poggio C, Dagna A, Colombo M. Decalcifying Effect of Different Ethylenediaminetetraacetic Acid Irrigating Solutions and Tetraclean on Root Canal Dentin. J Endod 2012;38:1239-43. (Crossref) 
25. Clegg MS, Vertucci FJ, Walker C, Belanger M, Britto LR. The Effect of Exposure to Irrigant Solutions on Apical Dentin Biofilms In Vitro. J Endod 2006;32:434-7. (Crossref)

26. Scelza MF, Teixeira AM, Scelza P. Decalcifying effect of EDTAT, $10 \%$ citric acid, and 17\% EDTA on root canal dentin. Oral Surg Oral Med Oral Pathol Oral Radiol Endod 2003;95:234-6. (Crossref)

27. Cruz-Filho AM, Sousa-Neto MD, Savioli RN, Silva RG, Vansan LP, Pécora JD. Effect of chelating solutions on the microhardness of root canal lumen dentin. J Endod 2011;37:358-62. (Crossref)

28. Eldeniz AU, Erdemir A, Belli S. Effect of EDTA and citric acid solutions on the microhardness and the roughness of human root canal dentin. J Endod 2005;31:107-10. (Crossref)

29. Ballal NV, Mala K, Bhat KS. Evaluation of the effect of maleic acid and ethylenediaminetetraacetic acid on the microhardness and surface roughness of human root canal dentin. J Endod 2010;36:1385-8. (Crossref)

30. Pashley D, Okabe A, Parham P. The relationship between dentin microhardness and tubule density. Endod Dent Traumatol 1985;1:176-9. (Crossref)

31. Lewinstein I, Hirscfeld Z, Stabholz A, Rotstein I. Effect of hydrogen peroxide and sodium perborate on the microhardness of human enamel and dentin. J Endod 1994;20:61-3. (Crossref)

32. Oliveira LD, Carvalho CA, Nunes W, Valera MC, Camargo CH, Jorge AO. Effects of chlorhexidine and sodium hypochlorite on the microhardness of root canal dentin. Oral Surg Oral Med Oral Pathol Oral Radiol Endod 2007;104:125-8. (Crossref)

33. Fusayama T. Two layers of carious dentine. In: New concepts in operative dentistry. Chicago, IL: Quintessence Pub 1980:189.

34. Seaman H, Shannon IL. Fluoride treatment and microhardness of dentine. J Prosthet Dent 1979;41:528-30. (Crossref)

35. Burrow MF, Takakura H, Nakajima M, Inai N, Tagami J, Takatsu $T$. The influence of age and depth on dentin bonding. Dent Mater 1994;10:241-6. (Crossref)

36. Akcay I, Sen BH. The effect of surfactant addition to EDTA on microhardness of root dentin. J Endod 2012;38:704-7. (Crossref)

37. González-López S, Camejo-Aguilar D, Sanchez-Sanchez P, Bolaños-Carmona V. Effect of CHX on the Decalcifying Effect of $10 \%$ Citric Acid, $20 \%$ Citric Acid, or 17\% EDTA. J Endod 2006;32:781-4. (Crossref)

38. Haznedaroglu F. Efficacy of various concentrations of citric acid at different $\mathrm{pH}$ values for smear layer removal. Oral Surg Oral Med Oral Pathol Oral Radiol Endod 2003;96:340-4. (Crossref)

39. Calt S, Serper A. Time-dependent effects of EDTA on dentin structures. J Endod 2002;28:17-9. (Crossref)
40. Ballal NV, Kandian S, Mala K, Bhat KS, Acharya S. Comparison of the efficacy of maleic acid and ethylenediaminetetraacetic acid in smear layer removal from instrumented human root canal: a scanning electron microscopic study. J Endod 2009;35:1573-6. (Crossref)

41. Qing Y, Akita Y, Kawano S, Kawazu S, Yoshida T, Sekine I. Cleaning efficacy and dentin microhardness after root canal irrigation with a strong acid electrolytic water. J Endod 2006;32:1102-6. (Crossref)

42. Alaçam T. Endodonti. Nobel Kitabevi Adana, 2012, s 529-78.

43. Ferrer-Luque CM, Arias-Moliz MT, González-Rodríguez MP, Baca P. Antimicrobial Activity of Maleic Acid and Combinations of Cetrimide with Chelating Agents against Enterococcus Faecalis Biofilm J Endod 2010;36:1673-5. (Crossref)

44. Ballal NV, Kundabala M, Bhat S, Rao N, Rao BS. A comparative in vitro evaluation of cytotoxic effects of EDTA and maleic acid: root canal irrigants. Oral Surg Oral Med Oral Pathol Oral Radiol Endod 2009;108:633-8. (Crossref)

45. Hu X, Ling J, Gao Y. Effects of irrigation solutions on dentin wettability and roughness. J Endod 2010;63:1064-7. (Crossref)

46. Liu Y, Tjaderhane L, Breschi L, Mazzoni A, Li N, Mao J, Pashley $\mathrm{DH}$, Tay FR. Limitations in bonding to dentin and experimental strategies to prevent bond degradation. J Dent Res 2011;90:953-68. (Crossref)

47. Santos J, Carrilho M, Tervahartiala T, Sorsa T, Breschi L, Mazzoni A, Pashley D, Tay F, Ferraz C, Tjäderhane L. Determination of matrix metalloproteinases in human radicular dentin. J Endod 2009;35:686-9. (Crossref)

48. Quirynen $M$, Bollen $C M$. The influence of surface roughness and surface-free energy on supra- and subgingival plaque formation in man: a review of the literature. J Clin Periodontol 1995;22:1 14. (Crossref)

49. Estrela C, Estrela CR, Barbin EL, Spano JC, Marchesan MA, Pecora JD. Mechanism of action of sodium hypochlorite. Braz Dent J 2002;13:113-7. (Crossref)

50. Aranda-Garcia AJ, Kuga MC, Chavez-Andrade GM, KalatzisSousa NG, Hungaro Duarte MA, Faria G, Reis Só MV, Faria NB Jr. Effect of final irrigation protocols on microhardness and erosion of root canal dentin. Microsc Res Tech 2013;76:1079-83. (Crossref)

51. Garcia-Godoy F, Loushine RJ, Itthagarun A, Weller RN, Murray PE, Feilzer AJ, Pashley DH, Tay FR. Application of biologically oriented dentin bonding principles to the use of endodontic irrigants. Am J Dent 2005;18:281-90. 